\title{
Tamayo y los Contemporáneos El discurso de lo clásico y lo universal
}

\section{Introducción}

$\mathrm{E}$ N ESTE ESTUDIO analizaré por qué el uso, ahora cotidiano, de los términos "clásico" y "universal" en la crítica a Rufino Tamayo son producto de circunstancias históricas concretas. Sugiero que esos conceptos son el fundamento de un discurso que exhibió el vínculo estético surgido en las décadas de 1920 y 1930 entre Tamayo y los Contemporáneos. Por considerar que los discursos expresan propósitos prácticos, en este trabajo propongo que el discurso de lo clásico y lo universal, formulado por Tamayo y los Contemporáneos, tuvo la finalidad de consolidar el proyecto estético de esa generación.

En este análisis destacaré cuatro aspectos que permiten dilucidar un periodo cultural plural y polémico: I) la proclama de Tamayo y los Contemporáneos con que en 1928, anunciaron su vínculo estético, que se resume en la denuncia de "un mexicanismo aún no resuelto"; 2) el papel polémico que asumió esta coalición (Tamayo-Contemporáneos), la cual requirió un discurso que legitimara al grupo en el medio cultural; 3) su afiliación a la plástica purista como fundamento estético de su proyecto moderno-universalista y, finalmente, 4) las nociones de "clásico" y "universal" en los razonamientos que fundamentaron dicho discurso, en relación con el cual Jorge Cuesta, Xavier Villaurrutia y Rufino Tamayo figuraron como el teórico, el crítico y el artista, respectivamente. Así, en el análisis de la configuración de este discurso se identifican los actos, 
razonamientos y coincidencias estéticas que definieron la relación de camaradería entre Tamayo y los Contemporáneos y su afiliación estética. ${ }^{\mathrm{I}}$

\section{Configuración generacional}

En las primeras décadas del siglo xx, México era un mosaico de posibilidades estéticas; por ello, los distintos actores culturales buscaron alianzas. En este sentido, las convicciones estéticas tempranas de Tamayo y de los Contemporáneos compartieron un objetivo: vincular sus proyectos para consolidarse. ${ }^{2} \mathrm{Al}$ respecto, Villaurrutia señala:

No por simple azar sino por afinidades de elección y por correspondencia de ambiciones, Rufino Tamayo se encontró ligado al grupo de poetas mexicanos que, por conciencia y decisión propias, formaron una generación. Me refiero al grupo y a la generación de Contemporáneos, que por ese tiempo luchó intensamente por encauzar la poesía lírica mexicana, situándola dentro de sus verdaderos límites, negando y apartando abiertamente, rotundamente, la anécdota, la elocuencia, el prosaísmo; en una palabra, restituyendo a la poesía sus valores esenciales. No eran diversas la ambición y la intención de Rufino Tamayo desde el punto de vista de artista pintor. ${ }^{3}$

Tamayo, al recordar la camaradería del grupo, explica así la relación entre artista y grupo literario:

I. Para conocer un análisis historiográfico y formal de la obra de Rufino Tamayo, véase Ana María Torres Arroyo, "Identidades pictóricas y culturales de Rufino Tamayo de 1920 a 1960", tesis de doctorado en historia del arte, México, Universidad Nacional Autónoma de MéxicoFacultad de Filosofía y Letras, 2003. La autora presenta un análisis histórico e iconográfico del artista donde expone el significado cultural y estético que adquieren los elementos iconográficos en la obra del pintor.

2. En la década de 1920 , la relación entre Tamayo y los Contemporáneos ya mostraba cierta solidez. Ingrid Suckaer arguye que cuando Tamayo conoce a Carlos Chávez en el cine Olimpia en 1920, éste se encontraba en compañía de algunos escritores a los que posteriormente se conocería como los Contemporáneos. Cfr. Ingrid Suckaer, Rufino Tamayo. Aproximaciones, México, Praxis, 2000, pp. 89-90.

3. Xavier Villaurrutia, “Autobiografía en tercera persona”, en Miguel Capistrán, Los Contemporáneos por símismos, México, Consejo Nacional para la Cultura y las Artes (Lecturas Mexicanas), I994, p. 203. 
A Xavier Villaurrutia, que era el crítico del grupo, sí le interesó nuestra pintura. Los artistas que más ligados estuvieron a los “Contemporáneos” fueron Agustín Lazo, Julio Castellanos y Manuel Rodríguez Lozano. [...] Nosotros, nuestro grupo, nos reuníamos todos los sábados por la tarde para ir al Sanborn's de Madero o a jugar billar y luego al teatro lírico donde veíamos a Celia Montalbán y a Lupe Vélez. El teatro de revista llegó a interesarnos tanto que hasta escribimos una obra musical que se llamó Café negro. Salvador Novo y Pepe Gorostiza, Villaurrutia y Jaime Torres Bodet, escribieron los sketches; Lazo y yo hicimos la escenografía. ${ }^{4}$

La obra de arte, tanto para Tamayo como para los Contemporáneos, no fue narrativa ni representativa de la ideología revolucionaria o de los orígenes indígenas de la nación, pues debía ser un producto enigmático de la creatividad experimental. Tamayo pretendía que la composición plástica no re-presentara la realidad inmediata, sino que fuera un realismo poético. Villaurrutia concebía en un arte imaginativo que expresara pasiones e ideas indefinibles, y lo planteaba como la manifestación de la diversidad de luces del alma:

Como el hombre tiene, en su mundo interior, zonas conocidas y zonas inexplicadas, aéreas terrazas, oscuros subterráneos, donde surgen, circulan y luchan por expresarse o por reprimirse nuestras intenciones y deseos recónditos, nuestros sentimientos, nuestras larvas de ideas, nuestras ideas; entonces la obra de arte tendrá que ser la expresión exterior de este mundo viviente y diverso de fusiones invisibles de los innumerables y complejos seres que pueblan nuestro cuerpo interior. La obra de arte plástica se servirá de la materia — telas, colores, óleos, papeles_ como de un simple medio para hacerlas visibles. ${ }^{5}$

Tales correspondencias estéticas se evidencian en declaraciones y en reseñas críticas que el grupo literario elaboró acerca de las primeras exposiciones de Tamayo; estas reseñas cubren la primera exposición individual de 1926 y la Exposición de Pintura Actual que organizó la revista Contemporáneos en 1928. Además de editar el catálogo de la primera, que incluye un texto de Xavier Villaurrutia, asistieron a su inauguración Carlos Mérida, Agustín Lazo, Salva-

4. Rufino Tamayo, "Mi lenguaje: la pintura", en Raquel Tibol, Textos de Rufino Tamayo, México, Universidad Nacional Autónoma de México-Dirección de Literatura-Coordinación de Difusión Cultural (Textos de Humanidades), I987, pp. I28-I29.

5. Xavier Villaurrutia, "Pintura sin mancha", en Xavier Villaurrutia, Obras. Poesía, teatro, prosas varias, crítica, México, Fondo de Cultura Económica (Lecturas Mexicanas), 2004, pp. 744-745. 
dor Novo, Jaime Torres Bodet, Gabriel Fernández Ledesma, Gilberto Owen, el Dr. Atl, Rafael Heliodoro Valle, Ernesto García Cabral, Xavier Villaurrutia, Anita Brenner, Carlos Chávez, José Gorostiza y Artemio del Valle Arizpe, entre otros. ${ }^{6}$ Por su parte, Bernardo Ortiz de Montellano, Xavier Villaurrutia y Celestino Gorostiza elaboraron reseñas críticas que, junto al texto de Salvador Novo de 1924, forman parte de los primeros textos de crítica de arte sobre el pintor. ${ }^{7}$

Asimismo, Villaurrutia anunció a Rufino Tamayo y a Agustín Lazo como "los nuevos pintores: rebeldes y libres" ${ }^{8}$ Con estos adjetivos les concedía la categoría de "pintor actual", aspecto fundamental en su concepción de artista moderno. Posteriormente, en el catálogo de la exposición de 1926, Villaurrutia advirtió por vez primera la correspondencia entre el temperamento artístico de Tamayo y la poesía de Carlos Pellicer, al señalar que "todo lo que toque [el pintor] se llenará de sol", "grito y color", "grito silencioso", "sensualidad sin refinamiento", "sensualidad de indio y de primitivo". Todo esto, de acuerdo con él, hará de Tamayo "un mexicano excesivo, mexicano del trópico", y subrayaba el cáracter moderno y autóctono en la obra de Tamayo, procurando, a partir de estas ideas, su reconocimiento. Ortiz de Montellano apuntó que Tamayo "logra acordes precisos de belleza", "en colores que sienten sus ojos agudos como las notas de las canciones populares", y de esto deduce que "su sensibilidad de indígena lo guía seguramente". Gorostiza afirmó que lo distintivo de Tamayo radicaba en su "técnica moderna contemporánea", y denunciaba que este aspecto se hubiera usado en su contra: "[de ello] se ha pretendido hacer un arma para atacarlo por su europeísmo". Con todas estas aseveraciones, los Contemporáneos, además de incorporar en su estética la obra de Tamayo, se proponían legitimar ésta al enriquecer su significado e impulsar la fama del pintor. En este sentido señalaron dos características primordialmente: su sensibilidad indígena y su técnica contemporánea.

6. Anónimo, "Abrió su exposición pictórica el artista Sr. D. Rufino Tamayo. Distinguidas personas contemplaron y elogiaron la obra”, Excélsior, México, i de abril de I926, p. Io (2a. sección).

7. Xavier Villaurrutia, Catálogo de la Exposición Tamayo, México, Io de junio de 1926. Otro artículo que Villaurrutia escribió tempranamente fue "Los nuevos pintores", El Universal Ilustrado, México, 24 de septiembre de I925, pp. 30 y 7I; Celestino Gorostiza, "Rufino Tamayo abre una exposición con sus obras en la Galería de Arte Moderno", Excélsior, México, 20 de octubre de I929; Salvador Novo, "La última exposición pictórica juvenil", El Universal Ilustrado, México, I9 de junio de 1924, pp. 28, 29 y 4I; Bernardo Ortiz de Montellano, "La obra expresiva de Rufino Tamayo", Revista de Revistas, México, 4 de abril de 1926.

8. Villaurrutia, "Los nuevos pintores", op. cit. 
Años después, Villaurrutia, considerado el crítico de la generación, fue elegido para escribir el catálogo de la primera gran exposición retrospectiva de Tamayo, que abarcaría 20 años de su labor pictórica y que se montó en Bellas Artes en 1948. Villaurrutia aprovechó esta oportunidad para afianzar la noción de "universal" que en la polémica de 1932 el grupo había defendido;9 además confirió el título de "pintor universal" a Tamayo, para respaldar la dualidad "mexicano-universal" con que se autodefinía el pintor. Al respecto, Villaurrutia señaló: "la fidelidad a lo más recóndito de su raza y de su espíritu es lo que llamó y llama la atención en la pintura de Rufino Tamayo, y lo hace de él, al mismo tiempo, un pintor universal que puede alternar con los pintores europeos más avanzados". ${ }^{\text {Io }} \mathrm{El}$ momento era crucial, pues la exposición que se montó homenajeaba al artista y con ella se le reconocía oficialmente. Muchas reseñas críticas

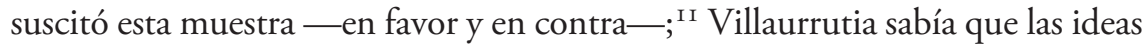
de su texto debían imponerse, ser contundentes y perentorias; y así fue porque, a partir de entonces, su escrito definió los términos en que se debatiría el prestigio de Tamayo. ${ }^{12}$ Así, pintura y poesía se muestran no como campos separados, sino como mancuerna, fortaleciéndose una a la otra. Como refiere Villaurrutia,

9. En los apartados "Juventud contra molinos de viento" y "Cuesta y Tamayo: el moderno tradicionalista y el mexicano universal", abordo la polémica de 1932; en "Lo clásico y lo universal", analizo el significado que adquirieron las nociones de "clásico", "universal" y "tradición” para Tamayo y los Contemporáneos. Vid. infra.

Io. Xavier Villaurrutia, Tamayo. Veinte años de su labor pictórica, México, Museo Nacional de Artes Plásticas, 23 de junio de 1948 (catálogo de la exposición del Instituto Nacional de Bellas Artes.

I I. Antonio Rodríguez escribió inmediatamente dos artículos en los que puso en tela de juicio la calidad estilística de la obra de Tamayo y señaló también que "si hay que buscar la mexicanidad en alguien — pese a la opinión de los críticos norteamericanos — no es seguramente en Rufino Tamayo". Cfr. Antonio Rodríguez, "20 años de labor artística se traducen en 80 bellos cuadros”, El Nacional, México, 24 de junio de I948, pp. I y 4 (2a. sección); y "Rufino Tamayo”, El Nacional, México, 30 de junio de I948, p. 5. Otros escritores que publicaron textos en favor de Tamayo fueron Jorge J. Crespo de la Serna, "En la magnífica exposición pictórica de Tamayo”, Excélsior, México, i de julio de 1948, pp. I y i I (2a. sección); Berta Taracena, "Tamayo, pintor con viejos antecedentes”, El Universal, México, I5 de julio de I948, pp. 4 y I 4 (ıa. sección); Regina Pardo, "Estudio sobre la pintura de Tamayo", El Universal, México, 21 de julio de 1948; Carlos Mérida, "Hondo contenido mexicano expresado en lenguaje mo-"(sic), El Universal, México, 26 de julio de 1948, p. 4; Carlos Fuentes, "Tamayo y yo", Novedades, México, 8 de agosto de 1948, p. 4, y Carlos Mérida, "Tamayo y el color", El Universal, México, 27 de julio de I948, p. 4.

I2. El primer texto que relacionó la obra de Tamayo con la noción de "universal" fue el catálogo de la exposición de Tamayo del 20 de octubre de 1929, escrito por Carlos Mérida y Carlos Orozco Romero; no obstante, como veremos más adelante, fueron los Contemporáneos quienes 
Sabemos que hay relaciones visibles a los ojos de todos y de un orden que podríamos llamar razonable, entre el mundo de las formas poéticas y el mundo de las formas plásticas. Hablo de ciertas afinidades estéticas que hacen posible reunir por un momento, en un mismo plano, por la fina retórica del dibujo, por el paladeo de ciertas delicadezas de un lenguaje de formas precisas, un poema y un cuadro excelentes. ${ }^{13}$

Villaurrutia se entregó a la tarea de convertir sus poemas en "objetos plásticos" e interpretó poéticamente las pinceladas de los nuevos pintores que, alejados de la exaltación de lo nacional, realizaban "pintura lírica”. Tamayo no sólo fue uno de estos nuevos pintores que coincidieron con las ideas estéticas de los Contemporáneos, pues también fue el artista que se convirtió en punto de referencia para el grupo; de hecho, estos escritores desarrollaron sus propias ideas estéticas a través de la crítica a la obra de Tamayo, evidenciando el fuerte vínculo entre intelectual y artista.

dotaron de significado el concepto "universal", debido a que el grupo atribuyó gran relevancia a dicho término al relacionarlo con la idea de lo clásico; por ello señalo, en el último capítulo de este trabajo, que fue Villaurrutia el primero que "estratégicamente" llamó "pintor universal" a Tamayo. Por otro lado, cabe agregar que Octavio G. Barreda también utilizó el término para referirse a la obra de Tamayo, pero él nunca fue considerado un crítico en su época. Barreda, incluso, en un artículo de I940, planteó perspicazmente que, a partir de la exposición que Tamayo había montado entonces en Nueva York, la crítica estadounidense "comienza a seńalarle como un pintor universal". Aunque su nota no refleja de modo particularmente objetivo el contenido de las críticas que Tamayo recibió en Nueva York, sí cumplía con seguridad el propósito de utilizarlas en el debate interno. En los artículos que Barreda menciona se exaltan las cualidades plásticas de la obra de Tamayo, pero no se hace referencia concreta la idea de universal; los artículos citados son anónimo, "Rufino Tamayo. The Wellknown Contemporary Mexican Artist...", Nueva York, Io de marzo de 1940 (CDRT); Anónimo, "At the Valentine Gallery, Rufino Tamayo’s Paintings...", Journal and American, Io de marzo de 1940; Henry Mc Bride, "Viva México. Exhibition in the Modern Museum Full of Excitement, Novelty and Charm", The New York Sun, I8 de mayo de 1940. El texto de Barreda se publicó en Letras de México. Gaceta Literaria y Artística Mensual, vol. II, núm. I8, I5 de junio de I940, p. 7. Para conocer mayor información al respecto, véase "Tamayo ante la crítica: lo clásico y lo universal", y "Xavier Villaurrutia, el crítico de la generación", en Érika Madrigal Hernández, "Tamayo y los Contemporáneos: el discurso de lo clásico y lo universal”, tesis de licenciatura, México, Universidad Nacional Autónoma de México-Facultad de Filosofía y Letras, 2006.

13. Villaurrutia, "Pintura sin mancha", op. cit., p. 740. 


\section{"Un mexicanismo aún no resuelto"}

La Exposición de Pintura Actual de 1928 exhibió la correspondencia estética entre Tamayo y los Contemporáneos. De ella se derivó la reflexión acerca de lo que el pintor oaxaqueño llamó "un mexicanismo aún no resuelto", para luego proponer un acercamiento a "los valores reales de la plástica mexicana". Por su parte, los Contemporáneos anunciaron como "pintura actual" la obra de los artistas cercanos al grupo. Recordemos que con el concepto "actual" se referían al carácter moderno, atemporal y vigente de la obra. En la Exposición de Pintura Actual que organizó la revista Contemporáneos, se presentaron obras de Tamayo, Carlos Mérida, Julio Castellanos, José Clemente Orozco, Manuel Rodríguez Lozano y Abraham Ángel. Incluso la prensa vinculó a los artistas con la revista al anunciarlos como "los artistas que conforman el grupo Contemporáneos" ${ }^{14}$ Sin negar la cercanía, Tamayo señaló con claridad, más tarde, quien había financiado y alentado la exhibición: "fue Antonieta Rivas Mercado quien apoyó con buena parte de los gastos y con la organización de la muestra [...] Contemporáneos imprimió el catálogo y la invitación y nos facilitó otras cosas, pero no dieron todo el dinero para hacer la exposición, como se ha dicho". ${ }^{15}$

Lo cierto es que el grupo literario fue el autor intelectual de esta exposición, como lo prueban las entrevistas realizadas por El Universal a los artistas que participaron en ella, pues los expositores agradecieron a los Contemporáneos por invitarlos y coordinar la muestra. ${ }^{16}$ Finalmente, ésta fue anunciada como la "Exposición de pintura organizada por la revista Contemporáneos". Pero, más allá del mutuo respaldo entre artista y grupo literario, ¿cuáles eran los objetivos que se buscaban con esta coalición?, ¿qué postulaba su discurso?, ¿qué estaba en juego en ese momento?

El día que se inauguró la Exposición de Pintura Actual, se le preguntó a Tamayo qué lo había motivado a "agruparse circunstancialmente" para efectos de exhibir su obra. Su respuesta dejó claro que el evento formulaba una versión del arte nacional distinta de la representación del México antiguo e indígena:

I4. Anónimo, "Fue inaugurada la Exposición de Pintura organizada por la revista Contemporáneos. Todos los lienzos son de una fuerte potencialidad técnica. Tamayo, destacado como fuerte colorista", El Universal, México, 8 de diciembre de 1928, p. I (2a. sección).

I5. Suckaer, op. cit., p. I I3.

16. Cfr. anónimo, "Carlos Mérida, en la exposición organizada por Contemporáneos", El Universal, México, I3 de diciembre de I928; anónimo, "Julio Castellanos, en la exposición organizada por Contemporáneos”, El Universal, México, i I de diciembre de 1928. 
Deseo acción en este medio en el que se habla mucho y no se trabaja y espero que este primer esfuerzo colectivo sugerirá un serio estudio que vendrá a determinar los valores reales de la plástica mexicana. El problema de nuestra pintura radica en su mexicanismo aún no resuelto. Hasta hoy se han hecho solamente interpretaciones folklóricas o arqueológicas, resultando de ello un mexicanismo de asunto en vez del verdadero mexicanismo en la esencia. ${ }^{17}$

Con esta declaración, Tamayo buscaba distinguirse del "mexicanismo no resuelto" de artistas como Diego Rivera; además, hacía ver que entendía su intervención en el ámbito artístico como parte de una controversia, ya que "los valores reales de la plástica mexicana” estaban en cuestionamiento perpetuo. De ahí la pretensión de que la muestra sugiriera un estudio de los valores reales del arte local, con lo que implícitamente se descalificaban los otros esfuerzos por carecer de profundidad y propender a la falsificación.

Así como Tamayo declaró en la entrevista que deseaba "determinar los valores reales de la plástica mexicana”, cabe reflexionar que, con el título "Exposición de Pintura Actual” con que Contemporáneos anunció la muestra, el grupo proclamaba su actualidad y por lo tanto su vigencia; cualquier otro artista que no estuviera inscrito en esta exposición de "pintura actual" quedaba fuera del movimiento moderno, corría el riesgo de inscribirse en la historia como un trasnochado de su época y no podría aspirar a ser considerado un clásico. Por ello la idea de "actual" se relaciona íntimamente con la de clásico, pues la primera categoría abriría camino a la segunda. Claudia A. Herrera reflexiona sobre la importancia que adquirió la noción de "actualidad" y señala que "Villaurrutia enarbolaba el concepto de 'hombre actual' para sí mismo y para su grupo cuando presentía ataques a su trabajo. El arte actual era una manera de proponer la creación de un arte propio". ${ }^{18}$ Según este crítico, el valor de las artes plásticas radicaba en su vigencia, en su actualidad, y de ninguna manera en su exaltación de algún nacionalismo; es decir que, si el arte trasciende, ello ocurre por los valores propios de la obra y no porque se le inscriba en una circunstancia nacional; sólo así ésta aspirará a ser siempre actual, y, por lo tanto, un clásico.

I7. Anónimo, "Rufino Tamayo, pintor mexicano, nos habla de su arte", El Universal, México, 7 de diciembre de 1928 (las cursivas son mías).

18. Claudia A. Herrera Martínez, "Aproximaciones al horror en Xavier Villaurrutia a partir de José Clemente Orozco", tesis de licenciatura, México, Universidad Nacional Autónoma de México-Facultad de Filosofía y Letras, 2002, p. 9. 
Tanto en la propuesta de Tamayo — analizar el problema de un mexicanismo aún no resuelto, para determinar los valores reales de la plástica mexicana- como en la de los Contemporáneos — definir su propio proyecto como "moderno y actual"-, ambos aspectos sugeridos en la exposición de I928, se encuentra explícita la idea que tempranamente resultó estratégica en sus razonamientos: proponer una plástica actual y con ello aspirar a ser un clásico; esta noción de atemporalidad nos remite a las ideas de clásico y moderno que Jorge Cuesta articuló en sus textos de 1932, como veremos más adelante.

\section{Enlace de intereses}

En la década de I930, la relación entre Tamayo y los Contemporáneos era sólida, resultado tanto de sus afinidades estéticas como de una necesidad de autodefensa frente al nacionalismo oficial. Al respecto, Villaurrutia declaraba:

[tanto] los nuevos poetas mexicanos, [como] los nuevos pintores, viviendo en un medio hostil por indiferente, sin un público definido a quién dirigirse, realizan, no obstante, una obra que tiende a la unidad espiritual con el resto del mundo y que si aparece aislada estética y moralmente es porque se opone a la de los artistas que los precedieron, no en el mérito, sino en el tiempo. ${ }^{19}$

No obstante las analogías estéticas entre Tamayo y los Contemporáneos, cabe mencionar que el ámbito cultural resultaba más complejo de lo que aparentaba. No se puede hablar de grupos fielmente delineados, pues se aprecia una interacción entre los practicantes culturales. Así, artistas que habían sido cruciales en la nueva definición de lo nacional, como Carlos Mérida y José Clemente Orozco, fueron un referente para los teóricos y escritores cosmopolitas. Mérida definía lo nacional en términos de un viraje, en una frase por demás simple: "estoy pasando de ese nacionalismo tradicional al nacionalismo sustancial". ${ }^{20}$ Orozco, por su parte, se aventuró en su obra por una "estética del horror" que Villaurrutia definió como "una rara especie de belleza, [que] tiene la virtud de producir una embriaguez, un delirio que, en su caso particular,

I9. Villaurrutia, "Pintura sin mancha", op. cit., p. 740.

20. Anónimo, “Carlos Mérida...”, op. cit. 
toma la forma de horror" ${ }^{21}{ }^{21}$ Esta expresión fue concebida por Villaurrutia como "libre y actual"; asimismo, Agustín Lazo se sintió atraído por la obra tardía de Orozco, porque observaba que en sus murales "comenzaba a olvidar la anécdota y la literatura". ${ }^{22}$

En el ámbito de la literatura también es factible ver este traslape, tal es el caso de Julio Jiménez Rueda y Ermilo Abreu Gómez, quienes, pese a que en determinado momento hicieron fuertes declaraciones contra los Contemporáneos, posteriormente colaborarían con ese grupo. ${ }^{23}$ Por su parte, Tamayo y los Contemporáneos mostraron continuidad en su relación, debido a que a través de la obra pictórica o literaria hicieron efectiva su estética mexicano-universalista; Tamayo significó para el grupo la respuesta ideal frente a las pretensiones de los nacionalistas porque su pintura representaba una mexicanidad de esencia incuestionable. Si bien Tamayo adoptó, al igual que ellos, las innovaciones y libertades de la plástica internacional, su supuesto origen indígena ${ }^{24}$ lo convirtió en el candidato lógico para demostrar la inviabilidad de una estética meramente local. Por ello Villaurrutia y el grupo insistieron en que Tamayo poseía una "mentalidad netamente indígena con que observa, estudia y trata de representar el objeto, el mundo de la experiencia que lo rodea". ${ }^{25}$

21. Xavier Villaurrutia, "José Clemente Orozco", en Obras..., op. cit., p. 761.

22. Guillermo Sheridan, Los Contemporáneos ayer, México, Fondo de Cultura Económica, 2003 , p. 278.

23. Esos cambios sorprenden si consideramos la crítica tajante de los escritores mencionados en las décadas de I920 y I930. Sólo cabe recordar que en I924 Julio Jiménez Rueda cuestionó la falta de "virilidad" en la literatura; por otro lado, en I932, Ermilo Abreu atacaba los postulados del grupo literario y se refería a la obra de éste como la creación de una vanguardia en crisis. No obstante, tanto Jiménez Rueda como Abreu llegaron a colaborar con los Contemporáneos en el Teatro de Ulises, la revista Contemporáneos y El Hijo Pródigo. Vid. infra, "Juventud contra molinos de viento".

24. Respecto al supuesto origen indígena que mencionó Tamayo, Ana María Torres señala que esta idea, repetida tanto por el propio pintor oaxaqueńo como por muchos críticos, construyó un mito que identificó a aquél como "el indio Tamayo". Al defenderse tal idea se perseguían ciertos intereses, como el de utilizar lo indio para marcar en su pintura un "sello único". Cfr. Torres, "Identidades pictóricas y culturales de Rufino Tamayo de 1920 a 1960", op. cit.

25. Octavio G. Barreda, "Tamayo”, Letras de México. Gaceta Literaria y Artística Mensual, México, vol. II, núm. I8, I5 de junio de 1940, p. 7, en Rufino Tamayo: antología crítica, México, CREA-Terra Nova, I987, p. I5. 


\section{Juventud contra molinos de viento}

La revisión de valores en el ámbito artístico y literario desató entre intelectuales $\mathrm{y}$ artistas varias polémicas, que se iniciaron en $1928^{26}$ y se prolongaron hasta 1932. ${ }^{27}$ En este análisis del discurso de lo clásico y lo universal en la obra de Rufino Tamayo, resulta importante el estudio retrospectivo de tales polémicas, fundamentalmente por el peso de los debates en el ámbito cultural y, sobre todo, porque revelan dos aspectos que me interesa destacar: primero, la necesidad de agruparse a partir de amistades, afinidades e intereses estéticos, como sucedió con Tamayo y los Contemporáneos; en segundo lugar, porque en el clímax de estas pugnas, en 1932, Cuesta articuló en sus textos el discurso de lo clásico y lo universal, con el objeto de justificar el devenir literario del grupo y lograr una hegemonía cultural.

En 1928 se registraron dos polémicas originadas por el controversial ensayo de Julio Jiménez Rueda titulado "El afeminamiento en la literatura mexicana"28 y por la tesis del filósofo español José Ortega y Gasset desarrollada en La deshumanización del arte. ${ }^{29}$

En el texto de Jiménez Rueda, el autor cuestionó "la falta de virilidad en la literatura", atacando con ello la personalidad de algunos de los Contemporáneos. El punto medular era oponer las ideas "viril" y "afeminado"; distinguiendo como "literatura viril” la que tenía afinidad con las ideas procedentes de la revolución, y destacándola "por su espontaneidad, fuerza y por la armonía arquitectural de sus composiciones”. En contrapartida se señalaba como principal característica de la "literatura afeminada" la falta de originalidad y su alejamiento de lo nacional. Jiménez Rueda, aludiendo al trabajo de tra-

26. Al indagar el inicio de las pugnas surgidas entre críticos a principios del siglo xx, descubrí una de 1920 librada entre Carlos Mérida y Alfonso Toro. Cfr. Madrigal Hernández, op. cit.

27. Cabe reflexionar que el choque de estilos artísticos todavía era evidente en I947, año en que se inicia una polémica, particularmente entre Tamayo y Siqueiros, publicada por El Nacional y encauzada por las entrevistas del reportero Antonio Rodríguez en "La pintura mexicana está en decadencia, dice Tamayo", 22 de septiembre de 1947; “Cómo quiere que responda a Tamayo, en broma o en serio?", 24 de septiembre de 1947; "Orozco no cambia, no investiga, siempre se repite", 26 de septiembre de 1947; "Tamayo es de una ampulosa suficiencia, dice Siqueiros", 27 de septiembre de 1947; "Tamayo contesta desde Nueva York a David Alfaro Siqueiros", 2 I de octubre de 1947. Tal polémica se mantuvo latente por varios ańos.

28. Julio Jiménez Rueda, "El afeminamiento de la literatura mexicana”, El Universal, México, 2 I de diciembre de 1924 .

29. La primera edición de este texto se publicó en 1925 en la Revista de Occidente. 
ducción que realizaron los Contemporáneos, señala que esta "literatura afeminada" es representada por quienes en "el tiempo de su mayor actividad y celebridad" se han dedicado a hacer traducciones "o acomodos al castellano, declarándolos cosa propia". Éstos, añade el autor, "se depilan por coquetería las cejas y se untan la faz de polvos de arroz". Por su parte, José Gorostiza no tardó en responder a estos ataques en su artículo "Juventud contra molinos de viento", que publicó en la revista La Antorcha,${ }^{30}$ donde, además de condenar las consideraciones simplistas de "afeminamiento" o "reblandecimiento" con que él y su grupo habían sido atacados, confrontó la idea de "vieja” y "nueva” generación, estipulando que su grupo representaba a esta última. Asimismo, José Gorostiza señaló a sus contrincantes como intelectuales que, abanderando un revolucionarismo, se identificaban torpemente con la idea de virilidad; para él, esta absurda postura no representaba verdaderos adversarios, sino simples "molinos de viento". La diferencia entre vieja y nueva generación, radicaba en que la primera defendía los imaginarios construidos a partir de las ideas de lo "nacional" y lo "revolucionario", y la segunda proponía la creación de un lenguaje viable a partir de la apropiación de una tradición internacional, la cual Gorostiza denominó "cultura vital".

en el caso de la creación artística, la cultura es un antecedente histórico de donde se aprenden las normas de belleza, no más que para darles un sentido nuevo. La juventud persigue, a sabiendas, adquirir esa cultura vital, trascendente, que si no se traduce en citas de memorización irreprochable fecunda, sí, las facultades creadoras. $^{3 \mathrm{I}}$

Esta confrontación de lo nuevo y lo viejo refleja la configuración de la idea de lo moderno; para los Contemporáneos, ser moderno exigía expandir sus conocimientos, sin necesidad de que éstos provinieran del seno nacional; incluso debían suprimirse las fronteras en el saber. Asimismo, la idea de "tradición universal" que propuso Cuesta en 1932, con la que postuló a sus compañeros de grupo como los modernos tradicionalistas, nos remite a la noción de "cultura vital" utilizada por Gorostiza para defender al grupo en su artículo de 1925; con ello se observa una continuidad en el fundamento de la propuesta creativa del colectivo la cual

30. José Gorostiza, "Juventud contra molinos de viento", La Antorcha, México, 24 de enero de 1925 .

3. Idem. 
se definía sólo a partir de un imprescindible e innegable antecedente histórico occidental, enriquecido con el legado ancestral de la cultura mexicana.

Por otra parte, la tesis de La deshumanización del arte causó polémica por poner al descubierto las controversias estéticas existentes en México, pues fue utilizada perniciosamente contra quienes se identificaban con la literatura y el arte puros, como Tamayo y los Contemporáneos. ${ }^{32}$ De tal forma, ellos sintieron la necesidad de diferenciar su propuesta estética de lo que Ortega y Gasset denominó "la joven operación estética purista" — que según él tendría a deshumanizar el arte-, para evitar ser catalogados como artistas propensas a deshumanizar el arte, por su desapego de la plástica realista descriptiva y anecdótica.

Posteriormente, la publicación de la Antología de poesía mexicana fraguada por el grupo y firmada por Cuesta en 1928 agudizó la postura contra los Contemporáneos debido a que éstos destacaron la obra del grupo y rompieron así los esquemas tradicionales cual "Juventud contra molinos de viento". Al respecto, Renato González Mello señala que los Contemporáneos enarbolaban el concepto de "calidad" como argumento central de sus elecciones; además, señala que

la calidad siempre se referiría al objeto, a la obra, al texto. Así justificó Jorge Cuesta su antología: "Nuestro único propósito ha sido el de separar, hasta donde fue posible, cada poeta de su escuela, cada poema del resto de la obra: arrancar cada objeto de su sombra y no dejarle sino la vida individual que posee". 33

Esta controversia se prolongó hasta 1932, cuando apareció la publicación titulada - a manera de interrogante tendenciosa— “¿Está en crisis nuestra literatura de vanguardia?”, porque se refería a la obra de los Contemporáneos y ello provocó una polémica entre Cuesta y Abreu Gómez. ${ }^{34}$

En los escritos vinculados con ese debate, Cuesta, en actitud defensiva, se apropió de la idea de lo clásico y lo universal, y la exaltó, pues encontraba en este argumento el conducto ideal para fundamentar y legitimar su permanencia grupal y generacional; además, considerando la reciente desaparición

32. Vid. infra., parte titulada "Forma y poema", donde se aborda más profundamente la polémica surgida en torno a la obra La deshumanización del arte.

33. Renato González Mello, "Estudio preliminar", en La nube y el reloj. Pintura mexicana contemporánea, México, Universidad Nacional Autónoma de México-Instituto de Investigaciones Estéticas, 2003, p. 27.

34. Miguel Capistrán, Los Contemporáneos por sí mismos, México, Consejo Nacional para la Cultura y las Artes, 1994, p. I3. 
de la revista Contemporáneos, y "con Torres Bodet, Owen, González Rojo y Pellicer lejos del país, el grupo de amigos careció de contemporizadores que amortiguaran la disputa". De esta forma, la defensa emprendida por Cuesta en sus textos resultó crucial porque se publicó en un momento en que el grupo perdió cohesión y sus enemigos aprovecharon la crisis para exhibirlo y anunciar su inminente desaparición. ${ }^{35}$

\section{Lo clásico y lo univeral}

En los siglos XVII y XVIII, los valores estéticos grecolatinos, considerados "clásicos" desde el XvI, fueron elevados a canon universal de las artes en el mundo occidental. No obstante, como es sabido, la modernidad se planteó como una reacción frente a esos principios:

la modernidad estética bajo la apariencia de "romanticismo" definió por primera vez su legitimidad histórica como reacción contra los supuestos básicos del clasicismo, el concepto de una belleza universalmente inteligible e intemporal ha experimentado un proceso de erosión permanente. ${ }^{36}$

No obstante la depreciación de "lo clásico" en el debate artístico de la época, Tamayo y los Contemporáneos recurrieron a este concepto para referir la jerarquía y durabilidad de su obra. Fue así como Cuesta propuso a los miembros de su grupo como los modernos tradicionalistas que, sin romper tajantemente con la tradición, la mostraban revitalizada y se reconocían herederos de una tradición universal. "Clásico", decía Cuesta, es sinónimo de lenguaje y significación universal. ${ }^{37}$ Así, para alcanzar la perdurabilidad de un

35. El mismo Guillermo Sheridan (en México en I932: la polémica nacionalista, México, Fondo de Cultura Económica, I999) destaca la belicosidad de Cuesta en esta polémica en contraposición al silencio de la mayoría de sus compañeros los Contemporáneos. Cfr. "Los participantes: vanguardistas, nacionalistas, conservadores."

36. Matie Calinescu, Cinco caras de la modernidad. Modernismo, vanguardia, decadencia, kitsch, posmodernidad, Madrid, Alianza, 2003, p. I9.

37. Cfr. Jorge Cuesta, "Clasicismo mexicano", con El libro y el pueblo, México, agosto de I934, en Jorge Cuesta, Poemas y ensayos. II, Luis Mario Schneider (pról.), Miguel Capistrán y Luis Mario Schneider (recopilación y notas), México, Universidad Nacional Autónoma de México, I964, pp. 367-378. 
clásico, primero el individuo debe reconocerse en una tradición universal, no en un populismo. No en balde los Contemporáneos respaldaron la empresa de José Vasconcelos de publicar y difundir las lecturas Clásicos para niños. Además, Novo, Villaurrutia, Ortiz de Montellano, Torres Bodet y José Gorostiza formaron parte del grupo que elaboró esas antologías. Sobre esto, Gorostiza mostró claramente su apego a una tradición universal y lanzó un edicto contra los opositores al proyecto:

Entendamos, primero, que lo clásico no es inaccesible a la mentalidad normal. Es lo perfecto, tipo el mejor de una clase; pero sencillo en tal manera que todo escritor ambiciona su sencillez. No me explico por qué error de educación, por qué grave inconsciente, se infundió a la gente el miedo de lo clásico; mas quien ya lo tiene querrá mantenerse en él con apego de bestia. Es necesario, por eso mismo, recomenzar el conocimiento de las realizaciones humanas desde la generación niña, antes de que el prejuicio aniquile su receptividad. ${ }^{38}$

Por su parte, Cuesta pensaba que su grupo merecía la perduración propia de un clásico, debido a que procuraba renovar y no negar la tradición occidental. Se trataba de una innovación a partir de la cultura, de la tradición. Con esta idea, Cuesta intentaba denotar la retención y la reconfiguración de los valores estéticos perennes; por ello afirmaba que "la doctrina de estos tradicionalistas es sólo un vanguardismo que pretende adelantarse hacia atrás”. Invirtiendo las presunciones sobre la vanguardia, el escritor transformaría la fidelidad en innovación: lo que consiguen nuestros tradicionalistas — dirá Cuesta- es apenas revivir la tradición, su obediencia es una rebeldía; su tradición, un futurismo. Así, la trascendencia de una propuesta no se fundamenta en la negación o defensa de la tradición, sino precisamente en la continuidad e innovación de esta última:

Puede decirse que el artista clásico empieza por ser vanguardista, por diferir. Luego difiere del vanguardismo también. ¿Qué se hizo de Baudelaire, por ejemplo, el romántico? ¿Qué de André Gide, el simbolista? Su diferencia acabó por hacerse banalidad. Al revés de los que pretenden que su vanguardismo difiera o que los distinga su gregarismo tradicional o antitradicional. $\mathrm{Al}$ revés de los que pretenden

38. José Gorostiza, "Clásicos para niños", Excélsior, México, 22 de marzo de 1925. 
que los distinga su hora o su lugar de nacimiento, lo que comparten con cualquiera. $\mathrm{Al}$ revés de los que pretenden que los distinga América o México. ${ }^{39}$

Villaurrutia, por su parte, refirió la idea de clásico con relación a la de hombre actual. Para él, aprehender esta actualidad era adquirir libertad y con ello acrecentar su mundo sensible; el hombre actual se dotaba de agudeza para enfrentar las nuevas experiencias que le proponía el mundo moderno y que repercutían en una nueva configuración de su goce estético, pues "El hombre actual, más ambicioso y más sediento, espera del arte, sobre todo, una embriaguez, un delirio"..$^{\circ} \mathrm{El}$ hombre actual y libre aspiraría a trascender el tiempo y, con ello a alcanzar la permanencia de un clásico: "es preciso no despreciar esta palabra: actualidad. Pensemos que un autor clásico es el que tiene la dicha de ser actual siempre". ${ }^{\mathrm{I}}$

Por su parte, la idea de actual en Tamayo se relacionaría con una investigación de lo ancestral y lo moderno; siempre le interesó analizar la cultura popular y prehispánica, pero vinculada con un lenguaje donde convergieran las influencias que había recibido de las vanguardias, donde el significado de lo mexicano adquiriera una dimensión actual y universal. Tamayo señalaría: "Mi objetivo es tomar elementos del gran pasado plástico de mi país, recurrir a las formas y colores mexicanos, y fundirlos en una unidad moderna e internacional". ${ }^{42}$ Para el artista oaxaqueño:

La obligación del pintor es ser actual, estar muy consciente de lo que está sucediendo a su alrededor en el momento que está viviendo, y eso reflejarlo en su obra. El arte es la quintaesencia de la vida, es decir, tiene que reflejarla; por ello el pintor tiene que ser actual. Si un pintor se dedica a hacer cosas que recuerden a los pintores anteriores, porque eran muy buenos, está fuera de su época; simplemente copia. Cada momento necesita una manera de expresión distinta. ${ }^{43}$

Con esto Tamayo buscaba expresar su tiempo y ser un artista no sólo representativo de su época, sino esencial; un clásico. De igual forma, la pintura de Tamayo nos remite a tres características del clasicismo por excelencia: com-

39. Cuesta, "Clasicismo y romanticismo", en op. cit., p. I07.

40. Villaurrutia, "José Clemente Orozco y el horror", en Obras..., op. cit., p. 76r.

4I. Nota tomada de Sheridan, op. cit., p. 285.

42. Rufino Tamayo, "Afirmaciones", en Tibol, op. cit., p. 67.

43. Ibidem, p. 96. 
posiciones equilibradas, mesura y depuración en las formas y en los colores, y búsqueda de la armonía. Una obra actual interesaría no sólo al espectador local, pues motivaría un interés general, universal. Éste es uno de los postulados que Tamayo procuró señalar respecto a su obra:

¿Qué me diferencia de otros pintores mexicanos? Que entiendo hacer pintura universal en vez de pintura puramente localista. Es universal por el dinamismo característico de nuestra época, por la búsqueda de algo que es hoy, consciente o inconscientemente, la preocupación de la humanidad: el tiempo, el movimiento. ${ }^{44}$

Para Tamayo, las nociones de actual, clásico y universal se relacionan íntimamente; para alcanzar a ser clásico, un artista debe ser primero actual y universal.

No obstante las diversas reflexiones de los integrantes de este grupo acerca del tema que aquí se revisa, será Cuesta quien muestre especial claridad sobre el asunto y lo convierta en una de las más importantes premisas del grupo. Cuesta fue concebido, dentro y fuera del grupo, como el analista de los Contemporáneos; él será "el enemigo brillante" que, armado de una gran inteligencia, fragüe textos sustanciosos. ${ }^{45}$ Como tal, Cuesta lanzó a la luz sus escritos en respuesta a quienes sólo atacaban de manera automática y sin argumentos sólidos. Gilberto Owen recuerda que Cuesta siempre prefirió las normas universales por encima de las particulares. También hace notar que, desde sus primeros escritos en Ulises, ${ }^{46}$ "fue ésta una de las afirmaciones que con mayor ahínco sostuvo Cuesta en sus ensayos y en sus polémicas [...] Hablaba de ello con apasionada inteligencia, como de todos los temas que incitaban su interés, y su

44. Ibidem, p. 36.

45. De hecho, la reputación de crítico y analista excelente no sólo fue reconocida en el grupo; Luis Cardoza y Aragón describió en sus memorias la personalidad de Cuesta: más que en un "raro", habría que pensar en él como un heterodoxo armado de una inteligencia batalladora y poco dada a las habituales concesiones; indicará que el mayor infierno de Cuesta se encuentra precisamente en su virtud: "Vivió la agonía de entender y no aceptar; de no aceptar sin entender; su cultura fue el infierno de comprender y de crear o no esa cultura elaborada con tesón y tedio". No en balde, Sheridan, en su obra Los Contemporáneos ayer, dedicó todo un epílogo para exaltar la lucidez y perspicacia que descubrió en la personalidad de Cuesta por encima de sus compañeros. Cfr. Sheridan, op. cit., pp. 386-388, y Luis Cardoza y Aragón, El río. Novelas de caballería, México, Fondo de Cultura Económica, 1996, p. 391.

46. La revista Ulises imprimió su primer número en mayo de 1927. 
conversación..." 47 Owen, además, indica que, en la conformación del grupo Contemporáneos, "Cuesta se situó desde luego como su crítico más escrupuloso y exigente". Villaurrutia también recordará "la disciplina mental y la capacidad" de su amigo el alquimista.

Finalmente, fue en la polémica propiciada por la pregunta “¿Existe una crisis en la literatura mexicana de vanguardia?” donde Cuesta configuró estratégicamente las ideas de lo clásico y lo universal que brindaron un argumento al grupo. Por el contrario, para Cuesta sus contrincantes habían contestado de prisa y, con objeto de atacarlos, argüían y censuraban rasgos de la personalidad del grupo, como la ausencia de "virilidad" o el "afeminamiento". Estos textos nacían como flores silvestres: afloraban muchos críticos que respondían con ligereza, pero faltaba quien escribiera las críticas que consolidaran la obra. Este problema se evidenció en el polémico ambiente de la época, que tempranamente apreció Francisco Monterde: "Falta quien [sic] elabore las frases que consagran, las que el público — la masa - se encarga de repetir, creando así la popularidad, ya que no está capacitado para formarse, por sí mismo, opinión definitiva sobre las obras nuevas". ${ }^{8}$

Los objetivos de los contendientes en la polémica de 1932 eran claros: debilitar o afianzarse, es decir, determinar quiénes prevalecerían. Sagazmente, Cuesta advirtió este aspecto y presentó el discurso de lo clásico y lo universal para consagrar a su grupo, exponiendo al público y a sus contrincantes los razonamientos con que respondió por qué merecían permanecer y consolidarse las obras de este colectivo. Cuesta presentó tal discurso para justificarlos como los innovadores que preservaban la tradición. Estas ideas se articularon en los textos: "¿Existe una crisis en nuestra literatura de vanguardia?", "La literatura y el nacionalismo" y "Clasicismo y romanticismo". Ahí se reúne un esbozo teórico de su pensamiento estético; con sus reflexiones, procuró dar una base formal al proyecto estético del grupo; tanto los Contemporáneos como Tamayo se sirvieron de estas ideas para definir su estética y proponerla como obra magistral.

47. Gilberto Owen, "Encuentros con Jorge Cuesta", en Obras, México, Fondo de Cultura Económica, I996, p. 245.

48. Francisco Monterde García Icazbalceta, "Existe una literatura mexicana viril”, El Universal, México, diciembre de 1924, p. 3. 


\section{Cuesta y Tamayo: el moderno tradicionalista y el mexicano universal}

De la afinidad estética entre Tamayo y los Contemporáneos me interesa reflexionar sobre dos aspectos: la defensa de una sola tradición, la universal, ${ }^{49}$ y su adhesión a la plástica purista. Ambos, además de ser una constante en las ideas estéticas de Tamayo, delinearon su estilo poético y polémico. Sobre estos conceptos los Contemporáneos y Tamayo definieron su estética como un moderno tradicionalismo y un mexicanismo universal, respectivamente.

En las primeras décadas del siglo xx, el "grupo sin grupo" fue prudente con las innovaciones. Lo novedoso de su obra no significó una ruptura total, como sí lo fue para los grupos de vanguardia en México; sin embargo, su actitud crítica representó una fractura con el pensamiento nacionalista. $\mathrm{Al}$ acercarse a la cultura europea, en particular a la francesa, Tamayo y el grupo demandaron continuidad y renuevo de la tradición occidental. Octavio Paz señalaría que su programa fue un intento de reunir la cultura local con Europa: "Todos ellos tenían una conciencia muy viva de pertenecer a Occidente y toda su empresa cultural puede definirse como una tentativa de recuperación y reactualización de los valores europeos. [...] su nacionalismo era un universalismo y [...] ser mexicano, para ellos, significa reinsertarse en la tradición europea" ${ }^{50}$

Este último aspecto le acarreó al grupo innumerables críticas. Era un momento en que se exhortaba al artista a exaltar lo nacional y lo revolucionario, y la mayoría lo hacía. El gobierno de Plutarco Elías Calles apoyaba el nacionalis-

49. Acerca de la idea de universalismo que se muestra como una constante en las reflexiones de Cuesta, cabe considerar la relación de amistad que mantuvo con Samuel Ramos; la inquietud acerca de la noción de universal la mostraron en sus colaboraciones en la revista Contemporáneos. Samuel Ramos, a diferencia de Cuesta, unificó sus reflexiones acerca de lo universal en su libro El perfil del hombre y la cultura en México. Respecto a los matices que se encuentran en sus respectivas reflexiones, Octavio Paz señala que "Mientras Samuel Ramos descubre el sentido de algunos de nuestros gestos más característicos — exploración que habría que completar con un psicoanálisis de nuestros mitos y creencias y un examen de nuestra vida erótica-, Jorge Cuesta se preocupa por indagar el sentido de nuestra tradición." (El laberinto de la soledad, México, Fondo de Cultura Económica, 1994, p. 173). Los textos de Samuel Ramos, El perfil del hombre y la cultura en México, México, Universidad Nacional Autónoma de México, 1934 y Hacia un nuevo humanismo, programa de una antropología filosófica, México, La Casa de España en México, 1940. Leopoldo Zea, En torno a una filosofía americana, México, El Colegio de México, 1945, forman parte de algunas de las principales disertaciones filosóficas de la época que tuvieron conexión con la idea de universalismo.

50. Octavio Paz, Xavier Villaurrutia en persona y en obra, México, Fondo de Cultura Económica, 2003, p. 75 . 
mo artístico para legitimar su proyecto autodenominado revolucionario. En este contexto, el pensamiento de los Contemporáneos representaba una resistencia a la subordinación política del arte y del intelecto. Tal necesidad de autonomía, unida al rechazo de las "falsas novedades" de las vanguardias, condujo al grupo a concebirse como heredero de la tradición universal.

En general, el término "tradición" se refiere a la transmisión generacional de los hechos históricos, doctrinas, leyes y costumbres, y por "universal" se entiende todo lo que ocupa a todo el mundo y relativo a todos los hombres. Los Contemporáneos denominaron "tradición universal" a la preservación y fusión de la herencia europea y nacional, sin restringir su perspectiva a lo meramente local. No obstante, el término universal resulta ambicioso, debido a que la herencia que recibieron fue la tradición occidental, y en gran medida francesa. Ese legado, que no se limitó a lo nacional y que los miembros del grupo denominaron "tradición universal", se reflejó en la influencia de artistas y escritores extranjeros a los que dedicaron artículos, reseñas y traducciones publicadas en la revista Contemporáneos. ${ }^{5 \mathrm{I}} \mathrm{El}$ grupo mostró gran interés por conocer a muchos de los autores que resultaban trascendentes en la cultura europea y por reconocerse en ellas. ${ }^{52}$ En sus memorias, Torres Bodet propuso una definición de universal: "Ser universal no es, sin duda, saberlo todo. Es, más bien, adiestrarse a

5I. En esta revista encontramos reseńas acerca de autores franceses como Jean Cocteau, André Gide, Marcel Proust, Paul Valéry, George Braque, Arthur Rimbaud, Stéphane Mallarmé, Henri Beyle, Michel Eyquem de Montaigne, Honoré de Balzac y Gustave Flaubert. Fuera de la tradición francesa encontramos a David Herbert, John Gould Fletcher, Thomas Stearns Eliot, William Blake y Juan Marinello. Respecto a las influencias literarias del grupo, Guillermo Sheridan seńala que "Después de la francesa, es la espańola la que más conformó el estilo y los objetivos de la incipiente narrativa mexicana de ese momento. Villaurrutia seguía, por ejemplo, a un narrador que le parecía deslumbrante: Juan Chabás; Torres Bodet se alineó a la derecha de Benjamín Jarnés, el más publicado y comentado por los Contemporáneos, [...] Gorostiza — certero crítico de narrativa - fue seguidor perspicaz de la obra de Antonio Espina”. Cfr. Sheridan, op. cit., p. 25 I. No debe dejarse de mencionar también la temprana influencia del autor español Juan Ramón Jiménez. Otros más fueron Liev Nikoláievich, Fiódor Mijáilovich Dostoyevski, Charles Dickens y James Joyce.

52. Respecto al asunto de conocer y reconocerse en la cultura europea, Jaime Torres Bodet señala en sus memorias que fue Xavier Villaurrutia quien se encargó de abrir al grupo un amplio panorama de lo que acontecía en la literatura en el mundo occidental, debido a que fue un lector fervoroso de la Revista de Occidente. También de su trabajo de traducción emana cierta necesidad de descubrirse y reconocerse en los propios escritos de los autores, reflejada, por ejemplo, en la selección de las obras de André Gide que tradujeron Villaurrutia y Torres Bodet. Cfr. Jaime Torres Bodet, Tiempo de arena, México, Fondo de Cultura Económica, 2002, p. I84. 
fin de percibir en cada circunstancia el mayor número posible de puntos de vista y hallar así, en cada acontecimiento, la esencia que lo vincula con el conjunto del universo" ${ }^{53}$ Esta idea refleja la premisa del grupo, fundamentada en su curiosidad y deseo de expandir su conocimiento sobre la cultura europea y sus innovaciones estéticas; al mismo tiempo, esto posibilitaba su inserción en ella. Asimismo, la postura del grupo, de continuidad y renovación de la tradición universal, articulada en la obra de Cuesta, planteó la necesidad de despertar una actitud crítica: casi todos, si no puede decirse que son críticos, han adoptado una actitud crítica. Su virtud común ha sido la desconfianza, la incredulidad. Lo primero que se negaron fue la fácil solución de un programa, de un ídolo, de una falsa tradición. Nacieron en crisis y han encontrado su destino en esta crisis: una crisis crítica. ${ }^{54}$

Tal actitud es lo que permitió a los Contemporáneos rechazar o aceptar la influencia tanto de la realidad mexicana como de la herencia occidental, sin perder de vista su propuesta generacional: la continuidad y renovación de la "tradición universal" en contraste con la prolongación de una "tradición nacional”. La actitud crítica, dirá Cuesta,

Es la única que hace valer la actitud y la obra de los otros; [... H Hace valer lo mismo la literatura y el arte franceses, que los de cualquier otro país. Admite cualquier influencia. Admite la cultura y el conocimiento de las lenguas. Admite viajar y conocer gentes. Admite encontrarse frente a cualquier realidad, aun la mexicana. Es una actitud esencialmente social, universal. Revolucionarismo, mexicanismo, exotismo, nacionalismo, son en cambio puras formas de misantropía. 55

Tamayo y los Contemporáneos optaron por defender una tradición universal que acrecentó su panorama intelectual. "La originalidad de la poesía mexicana, no puede venirle sino de su radicalismo, de su universalidad”, dirá Cuesta. Su lirismo se plasmó en la plástica purista, la cual, a pesar de ser influida por el pensamiento innovador de las vanguardias, no representó un choque con la tradición como sí lo fue para los movimientos estrictamente vanguardistas; no en balde Villaurrutia ironiza al señalar que el estridentismo de "Manuel Maples Arce supo inyectarse, no sin valor, el desequilibrado producto euro-

53. Ibidem, p. 277.

54. Jorge Cuesta, “¿Existe una crisis en nuestra literatura de vanguardia?”, El Universal Ilustrado, México, I4 de abril de 1932 y en Poemas y ensayos, op. cit., pp. 9I-92.

55. Ibidem, p. 94 . 
peo de los ismos". ${ }^{56}$ Incluso Cuesta rechazó la etiqueta "vanguardia" al definir claramente la postura de su grupo en pro de la continuidad de la tradición y mantener así una distancia con la ruptura de las vanguardias. El razonamiento de Cuesta fusionó la tradición y lo moderno, y presentó a su grupo como "esos otros modernos: los tradicionalistas. Su ortodoxia es tan protestante, su tradicionalismo tan moderno, su clasicismo tan romántico, como el sentimiento de los primeros. [...] La doctrina de los tradicionalistas es sólo un vanguardismo que pretende adelantarse hacia atrás". ${ }^{57}$

Ese tradicionalismo será la contraparte que los Contemporáneos plantearon frente al nacionalismo. La defensa de una tradición mexicana les parecía demagógica, pues les resultaba imposible negar la continuidad del tronco occidental en la cultura mexicana. En consecuencia, para los Contemporáneos los nacionalistas son incapaces de una verdadera renovación, pues su arte sólo confirma erróneamente una tradición local. "Europa llaman a esta tradición que rehúyen [...] de allí es donde parte su nacionalidad, su originalidad: su estrechez de miras. No les interesa el hombre, sino el mexicano; ni la naturaleza, sino México; ni la historia, sino su anécdota local”, dirá Cuesta.

Ante esta ofuscación, el grupo ofreció una búsqueda del legado ancestral de la cultura, sin negar la inevitable aculturación que enriquece su herencia. Gilberto Owen expresaba lo gratificante que era aceptarse en la tradición y adoptar todo lo que enriqueciera la legitimidad de su obra: "la raíz enterrada en la tradición, toda la poesía anterior contenida en el tallo, no para continuarse en orden sucesivo, sino para renovarse, para remozarse toda en el fruto nuevo de sabor inconfundible". ${ }^{58}$ Para los Contemporáneos la poesía no expresaba una entidad limitada y sus producciones no pretenden obtener la etiqueta de "poesía mexicana"; en cambio, desean entrar en el orden universal, restaurando el mexicanismo original de quienes, como Ramón López Velarde, habían sido utilizados como banderas ideológicas para crear un mexicanismo impostado. Como afirmó Torres Bodet, "[su] mexicanismo que, profundo y admirable en él, ha quedado como simple fórmula, es decir, como falsa epidermis en las poesías de sus imitadores, convirtiéndose así, de paisaje que era, en escenario, y de vestido en disfraz". 59

56. Villaurrutia, "La poesía de los jóvenes de México", en Obras..., op. cit., p. 827.

57. Cuesta, "Clasicismo y romanticismo", en Poemas y ensayos, op. cit., p. I02.

58. Gilberto Owen, "Biombo. Poemas de Jaime Torres Bodet", en op. cit., p. 215.

59. Jaime Torres Bodet, "Perspectiva de la literatura mexicana actual. I915-1928", Contemporáneos, núm. 4, septiembre de 1928. 
Frente a la literatura nacionalista que propone una "vuelta a lo mexicano", Tamayo y los Contemporáneos optaron por emprender una defensa de la tradición universal. Cuesta argumentará que la tradición no se preserva, sino se vive; por eso, la tradición universal libera, no esclaviza; integra, no excluye ni despoja:

La tradición no es otra cosa que el eterno mandato de la especie. No en lo que perece y la limita, sino en lo que perdura y la dilata, se entrega. Así, pues, es inútil buscarla en los individuos, en las escuelas, en las naciones. Lo particular es su contrario; lo característico la niega. Aparte de que sólo la afirma su libertad, su superfluidad, su independencia de cualquier protección, ¿cómo podría protegerla el nacionalismo que no es sino la exaltación de lo particular, de lo característico? El nacionalismo equivale a la actitud de quien no se interesa sino con lo que tiene que ver inmediatamente con su persona; es el colmo de la fatuidad. Su principio es: no vale lo que tiene un valor objetivo, sino lo que tiene un valor para mí. ${ }^{60}$

Al definir, Cuesta, a la tradición como una perspectiva integral que rechaza la fragmentación de la cultura, lanzó un ataque contra aquellos que se afiliaron con el pensamiento nacionalista que exaltaba lo local. Tamayo coincidió con estas reflexiones; así, más que una innovación, su temprano distanciamiento de Rivera, Siqueiros y Orozco ocurrió cuando Tamayo presumió su oposición al referir que el mexicanismo de los anteriores "era de fachada, pintoresco, no de esencia" ${ }^{61}$ En contraparte, Tamayo destacó la afiliación de su pintura a una tradición universal. Para él, la búsqueda de lo universal fue perfectamente compatible con su acercamiento a las raíces nacionales:

6o. Jorge Cuesta, "La literatura y el nacionalismo", en El Magazine para todos, suplemento de El Universal, México, 22 de mayo de 1932, p. 3, y en Poemas y ensayos, op. cit., p. 96.

6r. Al respecto Rufino Tamayo declaró: "Cuando yo iba a la Escuela de Bellas Artes, un grupo de muchachos y algunos pintores ya más maduros sentíamos la necesidad de hacer algo, de buscar. En ese momento llegó Rivera de Europa, ya con un criterio formado. En torno a Rivera se congregaron todos los que deseaban hacer un arte que fuera característico de México. Otros artistas maduros -Orozco, Siqueiros - se unieron a Diego para formar el Sindicato de Pintores y Escultores. Querían hacer una escuela mexicana. Me distancié de ellos cuando vi que su mexicanismo era sólo de fachada, pintoresco, no de esencia. Los indios o los nopales pueden pintarlos, y muy bien, un artista norteamericano o europeo. Lo que los mexicanos debíamos descubrir, a través de la plástica, lo fundamental en el mexicano. Es decir, realizar con nuestro medio de expresión lo que aún ahora un grupo de filósofos está llevando a cabo con sus investigaciones acerca de México y lo mexicano. Tamayo, "Afirmaciones", en Tibol, op. cit., p. 47. 
mi pintura, además de ser mexicana por espíritu y por esencia, es internacional y contemporánea. Y mientras otros pretenden llevar el nacionalismo a tal extremo que segregan a México del concierto universal, mi lucha ha sido siempre porque sea lo contrario: que México contribuya con su arte, mientras aprovecha también la lección internacional.

Ahora bien, ¿en qué consistía artísticamente esa universalidad?: los problemas plásticos como el manejo del color, el diseño, el movimiento y el espacio fueron las principales preocupaciones estéticas que Tamayo consideró en su pintura. La temática del cuadro no fue su preocupación principal, debido a que privilegió el estudio de la esencia de las raíces indígenas en vez de la representación folclórica. Tamayo señaló el color y la forma como los elementos plásticos que conciliaban su moderna universalidad y su tradición local:

Este nuevo tipo de pintura que yo pienso originar en México deberá responder a una aspiración de fondo, a una expresión profunda de los caracteres de nuestra raza que la haga mexicana por esencia, captando para ello los colores, las proporciones y el sentido de las creaciones precolombinas y su fuerza vital y su contenido, pero revitalizados con los modernos recursos técnicos [...] El tema es indiferente, se podrá pintar con ella un paisaje o un rascacielos, el propósito es ir hacia la entrańa de nuestra tradición y arrancar de ahí su verdadero espíritu. ${ }^{62}$

Tamayo, al igual que los Contemporáneos, no niega la tradición occidental, antes bien la adopta e intenta presentarla revitalizada, pero, además, para él fue importante enfatizar la esencia de lo mexicano. En su obra está el reconocimiento de la tradición y su renovación, de lo antiguo y lo moderno. Rufino Tamayo, en un afán de mostrar que no traicionaba a su raza indígena, destacó primeramente una tradición propia, nacional, que no resultara del aspecto superficial, sino de un profundo estudio de su cultura. Postuló un "mexicanismo de esencia” y con ello contrarrestó las continuas críticas de "pintor extranjerizante" que se le hacían, por no coincidir con las tendencias nacionalistas del momento. En este contexto, Tamayo propuso una diferenciación entre el

62. Clemente Cámara Ochoa, "Movimiento transformador de la pintura en el continente", El Universal, México, 1944. Nota tomada de Judith Alanís y Sofía Urrutia, Rufino Tamayo. Una cronología: 1899-1987, México, Museo Rufino Tamayo/Secretaría de Educación Pública-Instituto Nacional de Bellas Artes, 1987. 
mexicanismo profundo y el superficial: "para lograr una mexicanidad verdadera hay que ahondar en nuestra tradición, en la cual están guardados hasta los más leves rasgos de nuestra fisonomía como pueblo". ${ }^{63}$ En otras palabras, Tamayo sugería que apartarse del "folclorismo" era una forma de ahondar en la verdadera tradición y puntualizaba: "Lo que llamamos tradición mexicana es un agregado nacional a la cosa universal. Y es en la última donde se hallan los gérmenes del arte moderno". ${ }^{64}$ Se trataba de recibir su legado, pero además de agudizar el conocimiento del ser y su sensibilidad. De tal forma, según Tamayo, "para el artista, aún más importante que ser mexicano, paraguayo o francés, es ser universal. Para llegar a algo realmente original, nuevo, se ha de conocer, previamente, lo que otros han hecho antes y lo que otros están haciendo en cualquier rincón del mundo". Este proyecto, por tanto, asumía el programa de los Contemporáneos de crear un moderno tradicionalismo; en este sentido, Tamayo presentó un mexicanismo universal:

ser mexicano, nutrirme en la tradición de mi tierra, pero al mismo tiempo recibir del mundo y dar al mundo cuanto pueda, éste es mi credo mexicano internacional. [...] $\mathrm{El}$ arte moderno lo veo como el producto de una serie de experiencias que vienen de mucho más atrás que el cubismo; que llegan, cuando menos, al impresionismo [...] Lo que llamamos tradición mexicana es un agregado nacional a la cosa universal. ${ }^{65}$

Tamayo adoptó el legado ancestral de la tradición occidental y lo mostró revitalizado con su mexicanismo de esencia. Lo antiguo en el pensamiento de Tamayo fue su reconocimiento como indio zapoteca, heredero legítimo de la sensibilidad indígena: "como indio que soy, lo mexicano me sale espontáneamente", dirá en repetidas declaraciones. Lo moderno en su propuesta estética fue plasmar una visión contemporánea y universal de lo mexicano. En referencia a la tradición artística precortesiana, Tamayo afirmó: "Yo continúo esta tradición a la manera contemporánea". Ciertamente, "convertirse en 'una nación moderna' [así como en un individuo moderno] no quiere decir solamente adoptar técnicas de producción, sino insertarse en una tradición universal determinada, o inventar un nuevo proyecto, una nueva visión del hombre y

63. Tamayo, "Afirmaciones", en Tibol, op. cit., p. 45.

64. Ibidem, p. 37.

65. Ibidem, pp. 35-37. 
de la historia" ${ }^{66}$ Partiendo de esta reflexión, para Octavio Paz el error de algunos artistas mexicanos había sido el no incorporarse a la tradición universal, e imputaba a la revolución mexicana el conflicto de haber revelado al ser nacional sin producir una verdadera visión del mundo ni enlazar su descubrimiento a una tradición universal. ${ }^{67} \mathrm{Al}$ respecto, tanto Tamayo como el grupo de los Contemporáneos manifestaron esta inquietud y su proyecto estético estuvo guiado por el deseo de incorporarse a una tradición que rebasara lo meramente nacional. Esto llevó a cada uno a definirse como un "mexicano universal" y al grupo como los "modernos tradicionalistas".

Tanto Tamayo como los Contemporáneos guiaron su estética en defensa y renovación de una sola tradición, la universal; sin embargo, sus reflexiones e intereses no fueron idénticos; a Cuesta, a diferencia de Tamayo, no le interesó analizar la influencia de la tradición indígena en sus postulados, aspecto fundamental en las reflexiones de Tamayo.

\section{Forma y poema. "En defensa de lo usado"}

El rasgo que definió y caracterizó a Tamayo y a los Contemporáneos como la nueva generación - y con lo que además buscaron insertarse en la tradición universal— fue su afiliación con la plástica pura. Este partidismo se concibió en los círculos artísticos como una ruptura con los esquemas tradicionales apegados a la representación realista. Los opositores al arte puro en México atacaron esta postura, luego de definirla como un movimiento vanguardista, que fundamentalmente expresaba rechazo con el pasado y por lo tanto, ruptura con el pensamiento nacionalista. De tal forma, el texto de José Ortega y Gasset, $\mathrm{La}$ deshumanización del arte, pronto encontró simpatizantes entre los antagonistas al arte puro, pues fue utilizado como un arma para sustentar sus críticas a dicha corriente. De hecho, en la polémica que se desató en 1947 entre Tamayo y Siqueiros, mediada por el reportero Antonio Rodríguez en el diario El Nacional, este último retoma el texto de Ortega y Gasset para encasillar la obra de Tamayo en el arte que refiere dicho filósofo, en estos términos:

66. Octavio Paz, Tamayo en la pintura mexicana, México, Universidad Nacional Autónoma de México, I959, p. 9.

67. Ibidem, p. Iо. 
Todo parece indicar que se enfrentan, en la actualidad, dos tendencias importantes y diametralmente opuestas en la pintura: la heroica, revolucionaria, humana, basada en una calidad plástica de primer orden — la pintura que ustedes iniciaron [Rivera, Siqueiros y Orozco] —, y la pintura abstracta o semiabstracta, "deshumanizada" que Ortega y Gasset identificaba, alabándola, con los deportes y que no pretende ser más que plástica pura y poesía. ${ }^{68}$

En este sentido, la adhesión de Tamayo y los Contemporáneos a la estética purista manifestó un componente polémico; por ello procuraron situar su disidencia ante la vanguardia, buscando desligarse de los fenómenos de los que hablaba Ortega y Gasset y presentar su propuesta como una afirmación de lo humano en la obra.

Cada uno en su quehacer plástico y poético reconoció como norma estética de su moderna sensibilidad la depuración poética. Lo superficial, lo epidérmico, sólo era el coqueteo, porque lo esencial de la obra se encontraba en lo indefinido, en lo misterioso; esta estética se desprende de la servidumbre anecdótica, que sólo adopta el aspecto inmediato de la imagen. Con tal visión, la tarea principal del poeta será expresar con aparente sencillez y con sensibilidad inteligente una realidad desnuda. Gilberto Owen, en su Poesía — ipura? - plena, señaló esta operación poética como una afiliación al arte purista refiriendo los postulados de Paul Valéry:

Su fórmula estética se integraría por dos cualidades básicas, arbitrariedad y desinterés, y su formalidad expresiva —elaboración en metáforas de un sistema del mundo- requeriría una afinación del estilo a que obliga al escritor el nacimiento de un arte nuevo [...] Poesía plena, equilibrio: palabras nuevas, imágenes e ideas nuevas, y, por de dentro, presente e invisible, la puerta de Dios, el fluido [...] la poesía pura. ${ }^{69}$

A pesar de que el significado de lo "puro" se mostró ambiguo y controversial ${ }^{70}$ en los círculos literarios, al no existir una definición unánime de ellos,

68. Antonio Rodríguez, “¿Cómo quiere que responda...”, op. cit. Este artículo fue una respuesta a una entrevista que el mismo reportero realizó a Tamayo, titulada "La pintura mexicana está en decadencia...", op. cit.

69. Owen, "Poesía-¿Pura?", op. cit., p. 228.

70. En los círculos intelectuales de París, en octubre de 1925, cuando el abate Brémond abordó por primera vez el tema de la poesía pura tomando como ejemplo el trabajo de Paul Valéry, su discurso generó un fuerte debate en el que se confrontaron diversas posturas en torno a la poesía 
incluso en el círculo cultural parisino donde se originó, ${ }^{7 \mathrm{I}}$ Torres Bodet señala, en sus Memorias, que en su grupo el problema se propuso como una pugna entre la poesía llamada "pura” y la que ellos denominaron como impura, por anecdótica y descriptiva. Así, en la plástica mexicana el arte puro se presentó como contrario al arte anecdótico donde lo primordial era exaltar una temática nacionalista y/o revolucionaria; los Contemporáneos, por su parte, intentaron una reconfiguración en la producción poética y con ello la destrucción de ídolos consolidados. La operación artística que refieren los Contemporáneos estaría alejada del verso provisto de un ritmo determinado, acentuando su gusto por el verso libre, con longitud desigual y ritmo variado; refiriendo sentimientos, deseos, intenciones, ideas del ser, más que a las formas de la realidad. Cuando Villaurrutia señala que "no eran diversas la ambición y la intención de Rufino Tamayo desde el punto de vista de artista pintor", es porque en la ejecución pictórica de Tamayo se observan tres nociones medulares de la estética purista: rechazo al realismo descriptivo, búsqueda de las formas, colores y líneas esenciales, donde el "asunto"

pura. De hecho, entre Paul Valéry y el abate Henri Brémond se hizo visible una percepción distinta del término. Robert de Souza, uno de sus más convencidos partidarios y de los que más comprendieron a Brémond, lo puntualiza: "Una de las principales causas del debate fue creada por la palabra 'pura'. Valéry es el gran responsable, desde que la entendió como pureza química lograda por destilación voluntaria y absoluta”. Para Souza, esa pureza química de Valéry ha sido la causante de la confusión, pues actualmente se tiende a identificar el término poesía pura con la poesía que ha sido purificada en un proceso parecido al químico y muchos de los poetas que se consideran ellos mismos como poetas puros se rigen por lo expresado por el poeta francés. Por otra parte, Brémond justificaba su expresión de poesía pura, que había usado al prologar un libro ajeno, diciendo "que sólo había querido hacer alusión a la poesía que resultase mediante una especie de exhaustación, de supresión progresiva de los elementos prosaicos que hay en un poema [...]; es decir, que todo aquello que puede ser dicho, sin prejuicio, en prosa: todo lo que, siendo historia, leyenda, anécdota, moralidad, inclusive filosofía, existe por sí mismo, sin el concurso necesario del canto". Es así como el término "puro", desde sus orígenes, se mostró ambiguo y controversial. Cfr. Alberto Monterde, La poesía pura en la lírica española, México, Universidad Nacional Autónoma de México, 1953, pp. 6-7; Henri Brémond, La poesía pura con un debate sobre la poesía por Robert de Souza, Buenos Aires, Argos, I947.

7I. Precisar quién fue el primero que después del sustantivo "poesía" puso el adjetivo "pura" es difícil, pero sí podemos apuntar quién los usó así por primera vez, logrando atraer la atención de críticos y hombres de letras: Paul Valéry los empleó para hablar no de sus propias obras, sino de una ajena (Connaissance de la Déesse). Tal vez si este poeta hubiera utilizado el término "poesía pura" habría pasado inadvertido, de no ser por el abate Henri Brémond, quien lo hizo tema de una conferencia suya que más tarde suscitó una de las más apasionadas controversias. Cfr. Monterde, op. cit., pp. I. 2. 
o tema era parte de la obra, pero donde la calidad plástica resultaba lo primordial. Asimismo, dejando ver su identificación con esta corriente, Tamayo señaló: "mi pintura está orientada en la plástica pura. No purismo simplemente intuitivo. Sensibilidad e inteligencia juntas".$^{72}$ El pintor destacó la relevancia de la poesía en su quehacer plástico, aspecto que lo había llevado a recrear la realidad, descartando la representación en su obra: "No quiero retratar el árbol o el hombre, sino rehacerlos, 'recrearlos'. Para mí ésta es la función del arte. Y esta recreación se hace por medio de la poesía”. ${ }^{73}$

Su búsqueda de nuevas formas estará mediada por la mesura: "yo [...] elijo un tema muy simple y trato de abrir ventanas a la inteligencia y a la sensibilidad del espectador. Trato de eliminar lo superfluo, de llegar a la esencia”. Y concluye: "Para mí la poesía es ante todo armonía. Me esfuerzo siempre en lograr armonía en mis cuadros [...] La poesía nunca puede ser llamar al pan pan y al vino vino. La imaginación del espectador es tan importante como la del pintor" ${ }^{74} \mathrm{El}$ arte puro de Tamayo se concibe como un arte sutil y equilibrado, lleno de ideas más que de imágenes, con franco acercamiento a la poesía; la obra de arte para él es un "producto cuyo valor se deriva únicamente de sus cualidades plásticas", "Esencia plástica ordenada con un sentido poético dentro de la preciosa limitación del cuadro". Este arte puro no será un arte abstracto, sino una figuración cada vez más simplificada, como él lo señala en su artículo "En mis cuadros siempre hay figuración”. Para Tamayo será tontería decir que su pintura es abstracta, ya que ésta se fundamenta en la realidad, donde lo que pretende es reducir las formas a su carácter constitutivo, a lo más puro de una cosa. Este arte puro se fundamenta en una realidad que elimina los obstáculos que obstruyen un acercamiento a lo esencial. Al respecto, Tamayo señala: "La distribución y tamaño de las formas, el peso de los colores, el dibujo, todo ha de formar un ritmo que el ojo pueda seguir sin obstáculos. Desde luego no creo en el parecido fotográfico. Elimino detalles. [...] Procuro ir más y más hacia lo esencial, hacia decir lo que quiero decir con menos y menos elementos". 75

Este acercamiento a la estética purista no fue una estricta adhesión a la estética vanguardista. Tanto Tamayo como los Contemporáneos adoptaron la actitud de Torres Bodet, quien hablaba de tomar "con prudencia las inno-

72. Anónimo, "Rufino Tamayo, pintor mexicano...", op. cit., p. 6.

73. Tamayo, "Afirmaciones", en Tibol, op. cit., p. 65.

74. Ibidem, p. 64.

75. Ibidem, p. 65. 
vaciones y libertades de la nueva poética". ${ }^{76}$ En lugar de optar por la provocación, los Contemporáneos solían moderarla con la aplicación de la regla. Como sugiere Anderson Imbert, sus mejores momentos eran aquellos donde la imaginación los despeinaba, "sólo que lo hacían con la misma elegancia que otros ponen en peinársela". El grupo, concluye Imbert, "no se demoró en las arenas movedizas de la vanguardia". ${ }^{77}$ Tamayo, por su parte, mostró interés por la experimentación que le permitía la plástica de vanguardia, como la del impresionismo en su temprana obra, además de acusar la influencia del cubismo, el futurismo, el expresionismo y el primitivismo; ${ }^{78}$ la fusión de estas técnicas y su estudio del arte prehispánico y popular son lo que Ana María Torres ha señalado como "la mexicanidad como una vanguardia". ${ }^{79}$ No obstante la influencia recibida de estos movimientos, a Tamayo nunca le interesó afiliarse formalmente a grupos vanguardistas como lo fueron en México el planismo o el estridentismo abanderados por Fermín Revueltas y Manuel Maples Arce, o el cubismo y el surrealismo manifiestos en Francia. Incluso, en un afán por definir los valores de su pintura, hizo notar la distancia que en su momento tomó respecto de los postulados estéticos de los surrealistas. Para el pintor, el arte ha de reflejar las características de la vida en el momento en que se produce, no en relatos quiméricos. Tamayo fue directo cuando se le preguntó si había tenido alguna coincidencia con el movimiento surrealista y contestó así:

No. Allá, al principio de mi carrera, me interesó e hice algunos intentos. Fui muy amigo de Breton, y cuando llegué a París él me consideró dentro de su grupo. Yo no habría tenido ningún inconveniente, pero la cuestión es que de pronto me di cuenta de que el surrealismo no estaba de acuerdo con mi manera de sentir. [...] soy un pintor a quien lo objetivo le interesa mucho. En tanto que el surrealismo es todo lo contrario: subjetivo. Definitivamente, ése no es mi camino. ${ }^{80}$

76. Rebeca Barriga, Luis Mario Schneider, Guillermo Sheridan et al., Los Contemporáneos en el laberinto de la crítica, México, El Colegio de México (Cátedra Jaime Torres Bodet), 1994, p. 4.

77. Idem. Nota tomada de Rebeca Barriga.

78. Al respecto, Tamayo, en su texto "Afirmaciones", señala esto: "Alfredo Ramos Martínez, que dirigía la Academia de San Carlos cuando yo estudiaba en ella, me encaminó hacia el impresionismo. Después, el cubismo y el futurismo me ofrecieron sus conquistas técnicas”, p. 63.

79. Al respecto, Ana María Torres señala que "Tamayo usó un lenguaje experimental vinculado con la investigación formal y con un expresionismo pictórico asociado a las corrientes del 'primitivismo"”. Véase Torres, "La mexicanidad como una vanguardia”, op. cit., p. 94.

8o. María Idalia, "Es una tragedia que el sindicalismo quiera someter a la cultura: Tamayo", Excélsior, México, 8 de febrero de 1973. Nota tomada de Suckaer, op. cit., p. 343. 
A pesar de que Tamayo recibió influencia del surrealismo, incluso a través de los textos de Octavio Paz que tanto apreció; tanto el pintor como los Contemporáneos procuraron mantener su distancia de la vanguardia, mostrando su innovación como un renacimiento dentro de la tradición y no como una ruptura total, utópica, con ello intentaron desligarse de la deshumanización a la que refería Ortega y Gasset. Recordemos que el argumento central de Cuesta consistía en caracterizar a los Contemporáneos como artistas y escritores universales, en la medida en que los presentaba como los modernos tradicionalistas. ${ }^{81}$

Por otra parte, quienes se opusieron a la corriente purista caracterizaron esta "recreación" como una falta de rigor fundamentada en una cómoda y espontánea inspiración, crítica a la que Tamayo respondió así: "No creo en la inspiración. Hay que ejecutar el oficio como un artesano. La técnica se enriquece con el trabajo manual, con el dominio y habilidad de la mano que maneja el pincel". ${ }^{82} Y$ concluye: "el arte es también, además de dones naturales e inspiración, una voluntad permanente de trabajo, y de trabajo en libertad. Sin el trabajo no es tal, sino servidumbre, no tiene ningún valor creador ni ninguna posibilidad poética" ${ }^{83}$

Así, el texto La deshumanización del arte fue recibido por Tamayo y por los Contemporáneos como un recurso que sus adversarios podrían usar contra sus ideas estéticas. Por eso Tamayo declaró años después:

Uno de los libros que más me han impresionado fue La deshumanización del arte, de Ortega y Gasset. Me dejó una inquietud permanente. Yo que veía a mi alrededor tanto arte deshumanizado, desde el abstracto hasta el "mexicano" para turistas, me acordaba del libro de Ortega y, aunque parezca exagerado, me sentía estimulado a desmentirlo con mi obra. ${ }^{84}$

Recordemos que, si bien Ortega y Gasset se propuso analizar el arte nuevo para comprenderlo y valorar la joven operación artística que se manifestaba en torno al arte puro, lo cierto es que a lo largo de su texto muestra sus convicciones más arraigadas, porque enjuicia y desacredita el estilo de "los nuevos artistas", a los que culpa de tender a deshumanizar el arte:

8I. "Cuesta y Tamayo: el moderno tradicionalista y el mexicano universal". Vid. supra.

82. Ibidem, p. 3I (las cursivas son mías).

83. Tamayo, "Afirmaciones", op. cit., p. 69.

84. Ibidem, p. 65. 
Y buscando la nota más genérica y característica de la nueva producción encuentro la tendencia a deshumanizar el arte [...] Lejos de ir el pintor más o menos torpemente hacia la realidad, se ve que ha ido contra ella. Se ha propuesto denodadamente deformarla, romper su aspecto humano, deshumanizarla.

Con las cosas representadas en el cuadro tradicional podríamos ilusoriamente convivir [...] Con las cosas representadas en el cuadro nuevo es imposible la convivencia: al extirparles su aspecto de realidad vivida, el pintor ha cortado el puente y quemado las naves que podían transportarlas a nuestro mundo habitual. ${ }^{85}$

Ortega y Gasset enumeró siete tendencias del "nuevo estilo":

$\mathrm{I}^{\circ}$, a la deshumanización del arte; $2^{\circ}$, a evitar las formas vivas; $3^{\circ}$, a hacer que la obra de arte no sea sino obra de arte; $4^{\circ}$, a considerar el arte como juego, y nada más; $5^{\circ}$, a una esencial ironía; $6^{\circ}$, a eludir toda falsedad, y, por tanto, a una escrupulosa realización, en fin, $7^{\circ}$, el arte, según los artistas jóvenes, es una cosa sin trascendencia alguna. ${ }^{86}$

Entre estos postulados, Tamayo y los Contemporáneos procuraron contrargumentar los que podrían considerarse opuestos a su credo estético, así, rebatieron la idea de que el fundamento y la finalidad de la labor artística fuera la "representación", y no la "recreación". Respecto a la influencia que ejerce Ortega y Gasset sobre la obra de Tamayo, Rita Eder expone que "en este texto hay un rechazo al arte realista que es del gusto de las masas, pero también hay una preocupación por el destino del arte abstracto que induce a la deshumanización como una forma de destrascender del arte". Eder señala que "Ortega sugiere la posibilidad de una tercera vía que no sea la deshumanización, pero que tampoco sea el arte realista del siglo XIx". Y reflexiona que "quizás Tamayo sintió poder dar respuesta a esta tercera vía, donde aparece el hombre transformado" ${ }^{87}$

Otro aspecto que enjuicia Ortega es una idea fundadora en la estética del arte puro: el privilegio de la idea sobre el objeto. Al respecto, Ortega explica:

85. José Ortega y Gasset, La deshumanización del arte, Madrid, Alianza, 2002, p. 27.

86. Ibidem, p. 20.

87. Rita Eder, "El espacio y la posguerra en la obra de Rufino Tamayo", XIX Coloquio Internacional de Historia del Arte. Arte y espacio, Óscar Olea (ed.), México, Universidad Nacional Autónoma de México-Instituto de Investigaciones Estéticas, 1997, p. 249. 
Si ahora $[\ldots]$ tomamos las ideas según son —-meros esquemas subjetivos $-\mathrm{y}$ las hacemos vivir como tales, con su perfil anguloso, enteco, pero transparente y puro —en suma, si nos proponemos deliberadamente realizar las ideas—, habremos deshumanizado, desrealizado éstas. Porque ellas son, en efecto, irrealidad. Tomarlas como realidad es idealizar — falsificar ingenuamente— ${ }^{88}$

Los razonamientos de Ortega y Gasset originaron algunos textos contestatarios de Tamayo y los Contemporáneos. En I926, Owen, a propósito de la afiliación del grupo a la poesía pura, cuestionó con ironía los postulados del filósofo: "no nos estorba, [...] confesar la falta de deshumanización que la enriquece, y que Ortega y Gasset —que, por lo demás, niega la poesía actual— querría exigir al artista moderno. ¿Cabe en poesía la deshumanización?”89

Para Villaurrutia, la obra de arte refleja los aspectos terrenales, pero también las emociones, pasiones y deseos del artista, que no están predeterminadas por formas específicas, ésta manifestará:

la expresión exterior de este mundo viviente y diverso de fusiones invisibles de los innumerables y complejos seres que pueblan nuestro cuerpo interior. La obra de arte plástica se servirá de la materia — telas, colores, óleos, papeles— como de un simple medio para hacerlas visibles..$^{\circ}$

Tamayo, por su parte, cuando se publica La deshumanización del arte, enfatiza los lazos de su plástica con la realidad sensible; su argumento será una propuesta mediadora: ni abstracta ni realista-descriptiva, sino una obra intimista y poética, que brinda al espectador la oportunidad de hacer su propia interpretación. Para Tamayo, el artista tiene una inevitable relación con la realidad; no obstante, no debe de concebirse necesariamente como un imitador, sino como un "inventor de realidades". Esta preocupación formal de apego a la realidad y a la vez innovación de ella se relacionaba directamente con la negociación del binomio tradiciónmodernidad que los Contemporáneos le planteaban a Tamayo.

Se puede observar entonces que la idea de fidelidad-innovación en Tamayo y en los Contemporáneos fue una conciliación entre modernidad y tradición occidental, idea que guió al grupo por una ambiciosa estética entendida como

88. Ortega y Gasset, op. cit., pp. 40-4I.

89. Owen, "Biombo", op. cit., p. 217.

90. Villaurrutia, "Pintura sin mancha", op. cit., p. 746. 
una modernidad universalista, apartada de toda ruptura radical. Así, con su afiliación a la poesía pura, Tamayo y los Contemporáneos buscaron insertarse en la tradición universal y, al mismo tiempo, contrarrestar el componente polémico que adjudicaba Ortega y Gasset al arte puro, al imputarle la tendencia a deshumanizar el arte; en contrapartida, éstos presentaron el arte puro como un intento de agudizar la sensibilidad del Ser pues fomentaría la "recreación” y no la "representación". Su estética revelaba y expresaba los aspectos subjetivos que habitan el mundo terrenal del hombre, y que no obedecen a una forma definida.

\section{Una visión retrospectiva del discurso de lo clásico y lo universal en la crítica a Tamayo}

El discurso de lo clásico y lo universal, desde el inicio, de su configuración, se presentó como el argumento legitimador tanto para Tamayo como para el grupo de poetas y críticos de los Contemporáneos. Este par de conceptos no son sino la síntesis de su proyecto estético ante la modernidad y el cosmopolitismo que imperaba; con ello, anunciaron su deseo de no perecer en las arenas movedizas de lo vertiginoso de su tiempo.

Una vez pasada la necesidad de diferenciarse de los movimientos de ruptura denominados de vanguardia, la noción de "lo clásico y lo universal" siguió aplicándose en la crítica artística a Tamayo, ya no para afirmar la necesidad de investigar la tradición, abrazando un programa occidentalista y transhistórico como parte de su proyecto estético, sino como elementos aparentemente esenciales de la obra.

La conformación del discurso de lo clásico y lo universal, además de acercarnos a las ideas que impregnaron el pensamiento plástico de Tamayo, nos muestra el afán cultural renovador de su generación. Esta mutua intención renovadora hizo visible un rasgo que caracterizó a la época: la fuerte adhesión entre artista y poeta. Como bien señala Octavio Paz, en esta etapa aparece el poeta como la voz y la conciencia del artista; en el presente estudio se observa que tal fenómeno — surgido decisivamente en Occidente con la llegada de la modernidad—, también se generó en los círculos artísticos de México. ${ }^{9 \mathrm{I}}$ 
Las ideas de mexicanismo universal y de modernismo tradicional definieron la estética de Tamayo y de los Contemporáneos, coincidiendo ambos postulados en la afiliación a la plástica purista; de tal forma, su innovación no fue una ruptura vanguardista, porque sólo se resolvió después de haberse nutrido de la tradición, renaciendo dentro de ella. Con la configuración del discurso de lo clásico y lo universal, Cuesta procuró dar cuenta de las aspiraciones y propuestas estéticas de su grupo y con ello exponer por qué el grupo merecía la permanencia de un clásico. Teniendo como referencia las disertaciones de Cuesta y el peso que éste asignó al concepto de "universal", Villaurrutia fue el primero que confirió estratégicamente el título de "pintor universal” a Tamayo en I948, porque fueron los Contemporáneos quienes dotaron de significado la noción universal debido a que se encargaron de atribuir gran relevancia a dicho término al relacionarlo directamente con la idea de lo clásico.

La trayectoria artística de Tamayo y sus intereses con el grupo literario se resolvieron tempranamente en la exposición de 1928, que demostró sus propias aspiraciones: por un lado los Contemporáneos revelaban sus deseos de postularse como los "poetas actuales"; por otro, Tamayo expuso su deseo de "determinar los valores reales de la plástica", que se encontraban en cuestionamiento perpetuo. De hecho, estos dos aspectos tuvieron continuidad en su estética y con base en estas ideas se configuró el discurso de lo clásico y lo universal, articulado plenamente en los textos de Cuesta de 1932.

Jorge Cuesta y Xavier Villaurrutia se revelaron como la voz y la conciencia no sólo de Tamayo, sino de su futura crítica, ya que este discurso ejerció y sigue ejerciendo una influencia rotunda en la crítica de arte realizada a la obra de Tamayo. Finalmente, la conformación del discurso de lo clásico y lo universal surge de una trinidad estética: el teórico, el crítico y el artista que, utilizando el prestigio de "lo clásico y lo universal", compitieron por la legitimidad cultural, fundamentando en estas nociones su proyecto estético modernista. \$\$

repita. Entre I830 y 1930 los artistas formaron una sociedad dentro de la sociedad o, más exactamente, frente a ella. La rebelión de las comunidades artísticas contra el gusto de la Academia y de la burguesía se manifestó, con brillo y coherencia, en la obra crítica de algunos poetas: Baudelaire, Apollinaire, Breton", y concluye: "He mencionado únicamente a poetas franceses porque el fenómeno se produjo más acusada y decisivamente en París, que fue durante ese siglo el centro del arte moderno", en Octavio Paz, Los privilegios de la vista, México, Fondo de Cultura Económica (Lecturas Mexicanas), 1987, p. I2. 